\title{
NEWS
}

\section{AND ANNOUNCEMENTS}

"Estudos Sobre o Communismo" is a new journal published in Portugal by a group of working class historians. The journal analyses the communist movement in Portugal, with strong emphasis on the Portuguese Communist Party, as well as other organizations, movements, and leaders who claim to belong to communism. Through an exploration of working class history and the study of ideologies, the journal seeks to further understanding of the communist experience, and to integrate it into the history of twentieth-century Portugal.

A conference on "The Global Economy" will be held at Indiana University of Pennsylvania, October 24-26, 1984. The conference will explore the historical, contemporary and future aspects of the global economy. Conference participants will include Barbara Ehrenreich, Bennett Harrison, David Landes, and Immanuel Wallerstein. For additional information, contact Irwin Marcus, History Department, Indiana University of Pennsylvania, Indiana, Pa., 15707, or phone (412) 357-2237.

The "Social Action Collections at the State Historical Society of Wisconsin: A Guide" has recently been issued by the State Historical Society of Wisconsin. It catalogues the Histrocial Society's manuscripts on American social movements of the twentieth-century. Edited by Menzi L. Behrnd-Klodt and Carolyn J. Mattern, the fully-indexed guide will improve access to 454 collections. The Social Action Collection was begun in 1964 and includes extensive files on the southern civil rights movement. The collection also acquired the records of many anti-war and radical student organizations, including Students for a Democratic Society, National Peace Action Coalition, Student Mobilizing Committee Against the War In Vietnam, National Student Association, and Student Peace Union. In addition, the collection also encompasses the Society's older collections on radicalism, socialism, civil liberties, and the pursuit of social justice. Other related collections held by the Society include papers of Morris Hillquit and Alexander Meiklejohn; records of the National Urban Coalition, the Socialist Workers Party, and the Socialist Labor Party, and extensive documentation on blacklisting in the motion picture industry and the "Hollywood Ten." The guide is available for \$1 2 from the State Historical Society of Wisconsin, Publications Order Department, 816 State Street, Madison, WI 53706.

The Edgardo Leuenroth Archives, which deal with the history of the labor movement in Argentina, now has a catalogue of its holdings available from the Universudade Estudual de Campinas (UNICAMP) in Sao Paulo, Brazil. Leuenroth 
was a prominent Brazilian anarchist, born in 1881, whose vast collection of newspapers, books, pamphlets and journals was donated to the university in 1974, and is being made available to the public. For a copy of Cadernos do Arquivo Edgard Leuenroth, 1: Argentina, Fuentes para su historia social, contact the Arquivo Edgard Leuenroth, Instituto de Filosofia Ciêcias Humanas, UNICAMP, Cidade Universitatia, 13100 Campinas, SP Brazil.

The Archives of the Sailor's Union of the Pacific provides limited access to historians and researchers. The Archives consist of two facilities: a central Archive maintained at the Union's San Francisco Headquarters Building, and the Seattle Branch Archives held at the Union's Seattle Hall. The central Archive contains a number of important files on the 1934 West Coast maritime strike. The 1934 material can provide a day-to-day and, at certain points, hour-by-hour reconstruction of the role of Sailors in the strike. Other material includes correspondence from the San Francisco headquarters to the Seattle and Portland branches, and the file of E.B. O'Grady, San Francisco secretary of the Masters', Mates', and Pilots' organization. At present the S.U.P. Archives are not fully orgarized to accomodate work by scholars. Thus access tot hese collections is restricted. Qualified researchers may apply to the Sailors' History Project to examine copies of these documents. For further information, contact Stephen Schwartz, Sailors' Union of the Pacific, 450 Harrison Street, San Francisco, CA 94105, or telephone (415) 362-8363. 